ISSN 0206-5657. Вісник Львівського університету. Серія біологічна. 2021. Випуск 85. С. 45-52 Visnyk of the Lviv University. Series Biology. 2021. Issue 85. P. 45-52

УДК 57.044+631.45 HTTPS://DOI.ORG/10.30970/VLUBS.2021.85.05
ВПЛИВ КАМ'ЯНОВУГІЛЬНОГО ПОПЕЛУ ТА ГУМАТУ КАЛIЮ НА ВМІСТ
HITРОГЕНУ КАРБОНУ В СУБСТРАТI ВIДВАЛУ ВУГЛЕПРОМИСЛОВОСТI
Й ОРГАНАХ SORGHUM DRUMMONDII (NEES EX STEUD.) MILLSP. \& CHASE

\author{
С. Бешлей' ${ }^{1}$ В. Баранов², Я. Шпак ${ }^{2 *}$ \\ ${ }^{1}$ Інститут екології Карпат НАН України \\ вул. Козельнииькка, 4, Львів 79026, Україна \\ ${ }^{2}$ Львівський національний університет імені Івана Франка \\ вул. Грушевського, 4, Львів 79005, Україна \\ e-mail:dr.yaroslav.shpak@gmail.com; volodymyr.baranov@lnu.edu.ua
}

\begin{abstract}
Досліджено вміст амонійного, нітритного i нітратного нітрогену й органічного карбону в субстраті сіро-чорної неперегорілої породи з відвалу вугільної промисловості ЦЗФ (Центральної збагачувальної фабрики) ПАТ «Львівська вугільна компанія» (Львівська обл.), а також вміст органічного карбону і валовий вміст нітрогену в органах Sorghum drummondii (Nees ex Steud.) Millsp. \& Chase за впливу кам'яновугільного попелу з Добротвірської теплоелектростанції (Львівська обл.) та гумату калію «ГКВ-45» (виробництва ТЗОВ «ПАРК”, Львівська обл.). У субстраті породного відвалу знайдено підвищений вміст органічного карбону й амонійного нітрогену на фоні низького вмісту нітритного і нітратного нітрогену щодо умовно оптимальної грунтосуміші еталону. В органах $S$. drummondii за росту на субстраті породного відвалу виявлено низький вміст органічного карбону та валового нітрогену, а також значно підвищене $\mathrm{C} / \mathrm{N}$-співвідношення (в цій роботі відношення вмісту органічного карбону до валового вмісту нітрогену) порівняно з рослинами еталону. Додавання в субстрат породного відвалу кам'яновугільного попелу знизило вміст амонійного нітрогену й органічного карбону на фоні підвищення нітритного та нітратного нітрогену, а також органічного карбону й валового нітрогену в коренях, стеблах і листках досліджуваних рослин. Внесення гумату калію збільшило вміст нітритного та нітратного нітрогену в субстраті породного відвалу і вміст органічного карбону й валовий вміст нітрогену в органах $S$. drummondii. Зміна вмісту обох досліджуваних макроелементів у рослинах за впливу меліорантів зумовила зниження $\mathrm{C} / \mathrm{N}$-співвідношення в бік значень еталону. Вирощування S. drummondii протягом 95 діб збільшило вміст органічного карбону в усіх варіантах субстратів, за винятком породи 3 додаванням гумату калію, та зменшило вміст амонійного, нітритного й нітратного нітрогену в усіх досліджених варіантах субстратів без винятку. Відмічено, що спільний вплив кам'яновугільного попелу Добротвірської теплоелектростанції й гумату калію «ГКВ-45» на вміст карбону і нітрогену в субстратах породного відвалу ЦЗФ та рослинах $S$. drummondii сильніший, ніж тільки одного з цих меліорантів.
\end{abstract}

Ключові слова: C/N-співвідношення, породний відвал, кам’яновугільний попіл, гумат калію, Sorghum

Породний відвал ЦЗФ «Червоноградська» забруднює довкілля значною кількістю токсичних хімічних елементів і сполук [3]. Фітомеліорація знижує рухомість полютантів у відвалах вуглепромисловості, але ії проведення ускладнене значним дефіцитом рухомих форм макроелементів для живлення рослин [16]. Також відомо, що дефіцит нітрогену знижує продуктивність рослин [9], а співвідношення карбону до нітрогену важливе для оцінки стану екосистем [13]. Тому актуально досліджувати вміст і співвідношення цих макроелементів у субстратах і рослинах у процесі моделювання та проведення меліорації

(C) Бешлей С., Баранов В., Шпак Я., 2021 
породних відвалів вуглепромисловості. Породні відвали вуглепромисловості містять невеликі кількості органічного карбону [23], сульфатів і хлоридів амонію [12]. Вміст органічного карбону в них може варіювати від 1,21 до 14,60 \%, а валового нітрогену - від 0,023 до 0,291 \% [7]. Меліорація відвалів кам'яновугільним попелом стимулює акумуляцію органічного карбону [17] та підвищує вміст рухомих форм макроелементів, зокрема, й нітрогену [20]. Внесення гумату калію позитивно впливає на вміст органічного карбону в процесі рекультивації відвалів вуглепромисловості [21], покращує доступність нітрогену для рослин у сільському господарстві [9] та під час ревіталізації засолених грунтів [15]. Дослідження вмісту карбону й нітрогену в пагонах після 112 діб вирощування на умовно чистому субстраті показало C/N-співвідношення 31,4 [14]. Однак у літературі не знайдено досліджень сумісного впливу кам>яновугільного попелу та гуматів калію на вміст карбону й нітрогену в субстратах породних відвалів вуглепромисловості.

\section{Матеріали та методи}

Сіро-чорну неперегорілу породу відбирали з підніжжя південного схилу відвалу ЦЗФ (с. Сілець, Червоноградський р-н, Львівська обл.), а кам'яновугільний попіл з відвалу Добротвірської теплоелектростанції (смт Добротвір того ж району й області). Як умовно оптимальний субстрат для онтогенезу рослин, котрий для зручності назвали еталоном, використовували грунтосуміш торфу, листового перегною та піску зі співвідношенням складових 1:2:1. Субстрати контролю готували 3 породи відвалу, додавши в неї 1/10 грунтосуміші еталону, щоб уникнути швидкої загибелі рослин. У ролі дослідних варіантів були субстрати контролю з домішкою одного чи обох вищезгаданих дослідних меліорантів. Вплив попелу Добротвірської теплоелектростанції досліджували в концентрації 5 \% від маси субстрату породного відвалу, а вплив гуматів - шляхом одноразового першого поливу субстратів 150 мл 0,5 \% розчину гумату калію «ГКВ-45» виробництва ТЗОВ «ПАРК» (с. Великополе, Яворівський р-н, Львівська обл.), який, за даними інструкції, містив 16,6 \% валового карбону та 0,24 \% валового нітрогену. Насіння S. drummondii 4 доби пророщували в термостаті за температури $23^{\circ} \mathrm{C}$. Потім у горщики об'ємом 2 л висаджували по 15 проростків, які з липня до жовтня вирощували під відкритим небом на території біологічного факультету Львівського національного університету імені Івана Франка протягом 95 діб. Вміст амонійного нітрогену в субстратах визначали за реакцією з реактивом Неслера [4], нітритного з реактивом Грісса [2], а нітратного - згідно з методом Грандвальд-Ляжу [5]. Валовий вміст нітрогену в коренях, стеблах і листках визначали фотоколориметрично за реакцією з реактивом Неслера після мокрого озолення згідно з методом Піневич у модифікації Куркаєвої [4]. Органічний карбон у субстратах і вищевказаних органах $S$. drummondii визначали методом Нікітіна в модифікації Антонової та співавторів [1]. Середнє арифметичне, стандартне відхилення та статистичну достовірність одержаних результатів згідно з t-критерієм Стьюдента обчислювали за допомогою програми MS Excel 2007, а кореляційний аналіз проводили у програмі STATISTICA 10.

\section{Результати і їхнє обговорення}

У субстраті відвалу ми виявили нижчий вміст нітритного й нітратного нітрогену, ніж у субстраті еталону. Додавання попелу підвищило їхній вміст у субстраті відвалу, що можна пояснити наявністю в ньому калію і кальцію [6], які збільшують рухомість нітритів і нітратів [19]. Внесення гумату теж підвищило вміст цих форм нітрогену в субстраті, що можна пояснити здатністю гумату калію покращувати доступність макроелементів для рослин [11]. Слід зазначити, що внесення попелу й гумату разом збільшує концентрацію нітритного й нітратного нітрогену в субстраті відвалу сильніше, ніж внесення тільки одного з цих меліорантів (табл. 1). Вирощування рослин $S$. drummondii протягом 95 діб знизило вміст цих двох форм нітрогену в субстраті більшості дослідних варіантів (рис. 1), 
що, вочевидь, зумовлено поглинанням нітритів і нітратів коренями рослин [10], оскільки виявлено позитивну кореляцію їхнього вмісту з валовим вмістом нітрогену в рослинах (табл. 2). У субстраті відвалу знайдено високий вміст амонійного нітрогену. Додавання попелу його знизило (табл. 1), що можна пояснити взаємодією лужних металів попелу [6] 3 амонійними сполуками з утворенням леткого аміаку [22]. Вирощування рослин $S$. drummondii зменшило вміст амонійного нітрогену в субстратах усіх дослідних варіантів (рис. 1), що можна пояснити поглинанням цієї рухомої форми нітрогену рослинами [10]. Таке поглинання підтверджує позитивна кореляція вмісту амонійного нітрогену в субстраті 3 валовим вмістом нітрогену в органах S. drummondii (табл. 2).

Таблиця 1

Вплив попелу й гумату на вміст нітритного, нітратного й амонійного нітрогену в субстраті відвалу до і після вирощування $S$. drummondii $(\mathrm{n}=5)$

\begin{tabular}{|c|c|c|c|}
\hline \multirow{2}{*}{$\begin{array}{c}\text { Вміст нітрогену } \\
\text { в сухій масі }\end{array}$} & Субстрат & \multicolumn{2}{|c|}{ Вирощування } \\
& & \multicolumn{2}{|c|}{ S. drummondii } \\
\cline { 3 - 4 } & Еталон & $10,7 \pm 0,3$ & Пiсля \\
\hline Нітритний, & Порода & $2,95 \pm 0,24$ & $1,90 \pm 0,24$ \\
мг/кг & Порода+Попіл & $5,14 \pm 0,36^{*}$ & $3,19 \pm 0,23^{*}$ \\
& Порода+Гумат & $6,51 \pm 0,29^{*}$ & $3,91 \pm 0,31^{*}$ \\
& Порода+Попіл+Гумат & $7,53 \pm 0,36^{*}$ & $4,45 \pm 0,24^{*}$ \\
Нітратний, & Еталон & $12,1 \pm 0,3$ & $8,24 \pm 0,37$ \\
мг/кг & Порода & $3,98 \pm 0,29$ & $2,10 \pm 0,22$ \\
& Порода+Попіл & $7,08 \pm 0,22^{*}$ & $3,07 \pm 0,22^{*}$ \\
& Порода+Гумат & $5,86 \pm 0,27^{*}$ & $3,98 \pm 0,29^{*}$ \\
Амонійний, & Порода+Попіл+Гумат & $8,32 \pm 0,31^{*}$ & $5,20 \pm 0,29^{*}$ \\
г/кг & Еталон & $1,19 \pm 0,08$ & $0,92 \pm 0,06$ \\
& Порода & $2,34 \pm 0,07$ & $1,89 \pm 0,08$ \\
& Порода+Попіл & $1,83 \pm 0,06^{*}$ & $1,49 \pm 0,07^{*}$ \\
& Порода+Гумат & $2,43 \pm 0,04$ & $1,97 \pm 0,07$ \\
& Порода+Попіл+Гумат & $1,94 \pm 0,07^{*}$ & $1,33 \pm 0,07^{*}$ \\
\hline
\end{tabular}

Примітка: * - достовірна різниця значень досліду (з додаванням попелу й гумату) щодо контролю (без додавання попелу й гумату) за $\mathrm{p} \leq 0,05$

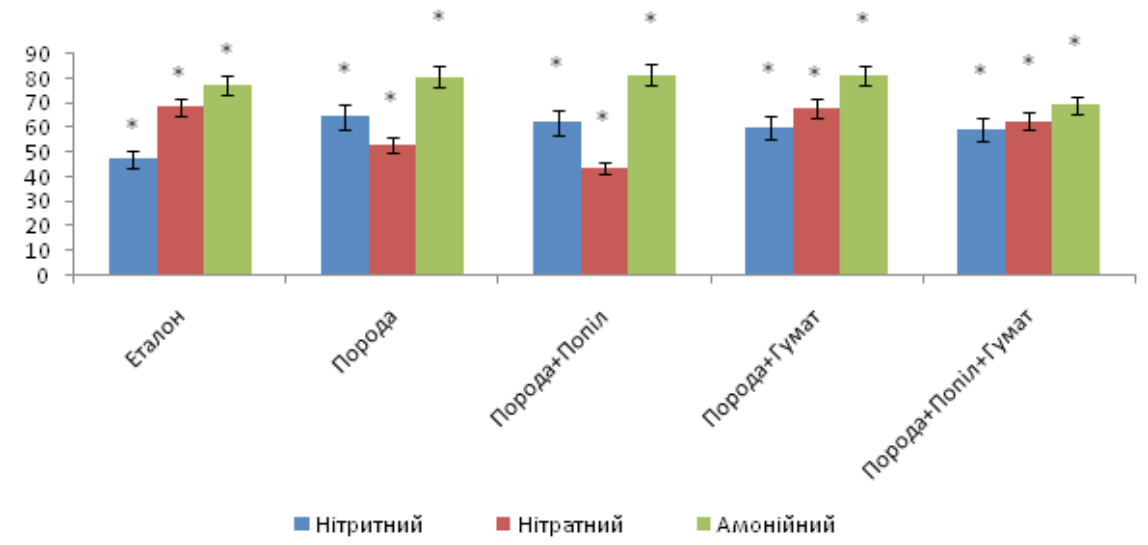

Рис. 1. Вміст нітритного, нітратного й амонійного нітрогену в субстраті відвалу за впливу вирощування $S$. drummondii $(\mathrm{n}=5)$, \%. Примітка: * - достовірна різниця значень після вирощування $S$. drummondii щодо субстрату до нього (100\%) за $\mathrm{p} \leq 0,05$ 
Також з'ясовано, що попіл і гумат у субстраті відвалу збільшують валовий вміст нітрогену в коренях, стеблах і листках рослин $S$. drummondii, що можна пояснити зниженням фітотоксичності завдяки впливу цих дослідних меліорантів. Внесення попелу й гумату разом сильніше збільшило вміст цього макроелементу в органах рослин, ніж внесення тільки одного з них (рис. 2).

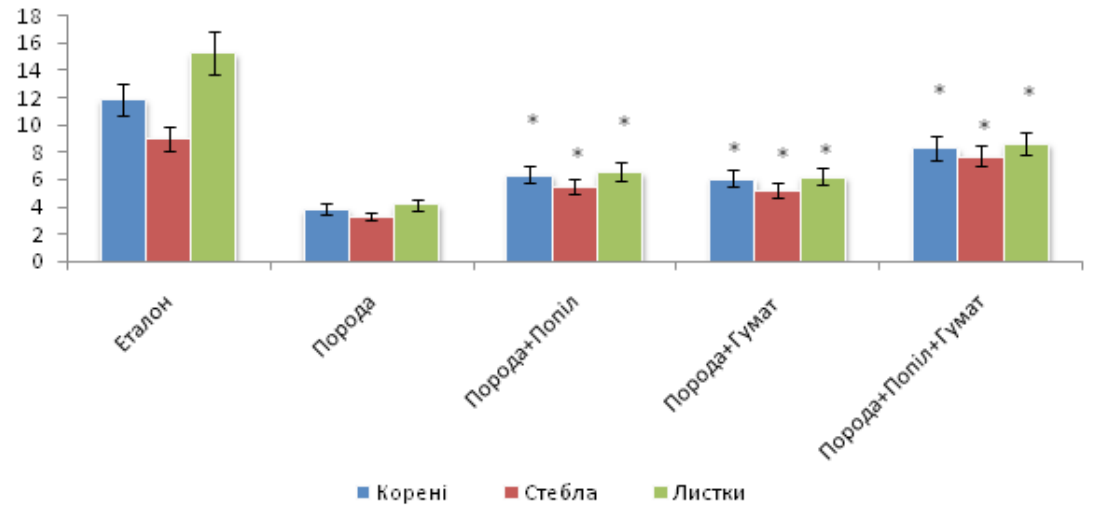

Рис. 2. Валовий вміст нітрогену в органах $S$. drummondii після росту на субстраті відвалу (n=5), г/кг сухої маси. Примітка: * - достовірна різниця значень досліду (з додаванням попелу й гумату) щодо контролю (без додавання попелу й гумату) за $\mathrm{p} \leq 0,05$

Таблиця 2

Коефіцієнти кореляції валового вмісту нітрогену $(\mathrm{N})$ в органах рослин iз вмістом амонійного $\left(\mathrm{NH}_{4}\right)$, нітритного $\left(\mathrm{NO}_{2}\right)$ й нітратного $\left(\mathrm{NO}_{3}\right)$ нітрогену в субстраті відвалу до і після вирощування $S$. drummondii $(\mathrm{n}=20)$

\begin{tabular}{|c|c|c|c|c|c|c|c|c|c|}
\hline & $\begin{array}{c}\mathrm{NH}_{4} \\
\text { До }\end{array}$ & $\begin{array}{c}\mathrm{NH}_{4} \\
\text { Після }\end{array}$ & $\begin{array}{l}\mathrm{NO}_{2} \\
\text { До }\end{array}$ & $\begin{array}{c}\mathrm{NO}_{2} \\
\text { Після }\end{array}$ & $\begin{array}{l}\mathrm{NO}_{3} \\
\text { До }\end{array}$ & $\begin{array}{l}\mathrm{NO}_{3} \\
\text { Після }\end{array}$ & $\begin{array}{c}\mathrm{N} \\
\text { Корені }\end{array}$ & $\begin{array}{c}\mathrm{N} \\
\text { Стебла }\end{array}$ & $\begin{array}{c}\mathrm{N} \\
\text { Листки }\end{array}$ \\
\hline $\begin{array}{l}\mathrm{NH}_{4} \\
\text { До }\end{array}$ & & $0,89 \#$ & $-0,27$ & $-0,30$ & $-0,74 \#$ & $-0,29$ & $-0,57 \#$ & $-0,57 \#$ & $-0,60 \#$ \\
\hline $\begin{array}{c}\mathrm{NH}_{4} \\
\text { Після }\end{array}$ & $0,89 \#$ & & $-0,45 \#$ & $-0,44$ & $-0,83 \#$ & $-0,51 \#$ & $-0,71 \#$ & $-0,75 \#$ & $-0,73 \#$ \\
\hline $\begin{array}{l}\mathrm{NO}_{2} \\
\text { До }\end{array}$ & $-0,27$ & $-0,45 \#$ & & $0,96 \#$ & $0,82 \#$ & $0,94 \#$ & $0,88 \#$ & $0,88 \#$ & $0,87 \#$ \\
\hline $\begin{array}{c}\mathrm{NO}_{2} \\
\text { Після }\end{array}$ & $-0,30$ & $-0,44$ & $0,96 \#$ & & $0,80 \#$ & $0,90 \#$ & $0,85 \#$ & $0,88 \#$ & $0,86 \#$ \\
\hline $\begin{array}{c}\mathrm{NO}_{3} \\
\text { До }\end{array}$ & $-0,74 \#$ & $-0,83 \#$ & $0,82 \#$ & $0,80 \#$ & & $0,82 \#$ & $0,94 \#$ & 0,92\# & $0,92 \#$ \\
\hline $\begin{array}{c}\mathrm{NO}_{3} \\
\text { Після }\end{array}$ & $-0,29$ & $-0,51 \#$ & $0,94 \#$ & $0,90 \#$ & $0,82 \#$ & & $0,88 \#$ & $0,89 \#$ & $0,86 \#$ \\
\hline $\begin{array}{c}\mathrm{N} \\
\text { Корені }\end{array}$ & $-0,57 \#$ & $-0,71 \#$ & $0,88 \#$ & $0,85 \#$ & $0,94 \#$ & $0,88 \#$ & & $0,91 \#$ & $0,96 \#$ \\
\hline $\begin{array}{c}\mathrm{N} \\
\text { Стебла }\end{array}$ & $-0,57 \#$ & $-0,75 \#$ & $0,88 \#$ & $0,88 \#$ & $0,92 \#$ & $0,89 \#$ & $0,91 \#$ & & $0,92 \#$ \\
\hline $\begin{array}{c}\mathrm{N} \\
\text { Листки }\end{array}$ & $-0,60 \#$ & $-0,73 \#$ & $0,87 \#$ & $0,86 \#$ & $0,92 \#$ & $0,86 \#$ & $0,96 \#$ & 0,92\# & \\
\hline
\end{tabular}

Примітка: \# - тут і далі наявність достовірної кореляції за p $\leq 0,05$ 
У субстраті відвалу знайдено більше органічного карбону, ніж у субстраті еталону (табл. 3). Вирощування рослин $S$. drummondii підвищило його вміст у субстратах із попелом і обома меліорантами разом (рис. 3), що можна пояснити виділенням органічних сполук коренями рослин [8]. У свою чергу, в коренях, стеблах і листках S. drummondii, яке вирощували на субстраті відвалу, виявлено менше органічного карбону, ніж у рослинах еталону, що можна пояснити його фітотоксичністю. Додавання в субстрат попелу й гумату збільшило вміст цього макроелементу в органах S. drummondii.

Таблиця 3

Вплив попелу й гумату на вміст органічного карбону в органах рослин і субстраті відвалу до і після вирощування $S$. drummondii $(\mathrm{n}=5)$, г/кг сухої маси

\begin{tabular}{|c|c|c|c|c|c|}
\hline \multirow{2}{*}{ Субстрат } & \multicolumn{2}{|c|}{$\begin{array}{l}\text { Вирощування } \\
\text { S. drummondii }\end{array}$} & \multicolumn{3}{|c|}{ Орган S. drummondii } \\
\hline & До & Після & Листок & Стебло & Корінь \\
\hline Еталон & $81,4 \pm 2,1$ & $94,5 \pm 1,9$ & $451 \pm 6$ & $381 \pm 4$ & $352 \pm 3$ \\
\hline Порода & $121 \pm 3$ & $130 \pm 3$ & $324 \pm 4$ & $262 \pm 3$ & $211 \pm 3$ \\
\hline Порода+Попіл & $104 \pm 2 *$ & $118 \pm 2 *$ & $379 \pm 4 *$ & $304 \pm 3 *$ & $269 \pm 3 *$ \\
\hline Порода+Гумат & $122 \pm 3$ & $131 \pm 3$ & $352 \pm 4 *$ & $298 \pm 3 *$ & $248 \pm 3 *$ \\
\hline Порода+Попіл+Гумат & $104 \pm 2 *$ & $114 \pm 2 *$ & $417 \pm 5^{*}$ & $336 \pm 4 *$ & $329 \pm 3 *$ \\
\hline
\end{tabular}

Примітка: * - достовірна різниця значень досліду (з додаванням попелу й гумату) щодо контролю (без додавання попелу й гумату) за $\mathrm{p} \leq 0,05$

Відмічено, що внесення обох меліорантів підвищує вміст органічного карбону в рослинах сильніше, ніж внесення тільки одного з них (табл. 3). Також виявлено негативну кореляцію вмісту карбону в органах $S$. drummondii 3 його вмістом у субстраті відвалу (табл. 4), що можна пояснити ймовірною взаємодією кореневих виділень і хімічних сполук неперегорілої породи, яка потребує додаткового вивчення. У субстраті відвалу з попелом знайдено менше карбону, ніж у субстраті без нього, що можна пояснити незольністю цього макроелементу [18, с.169].

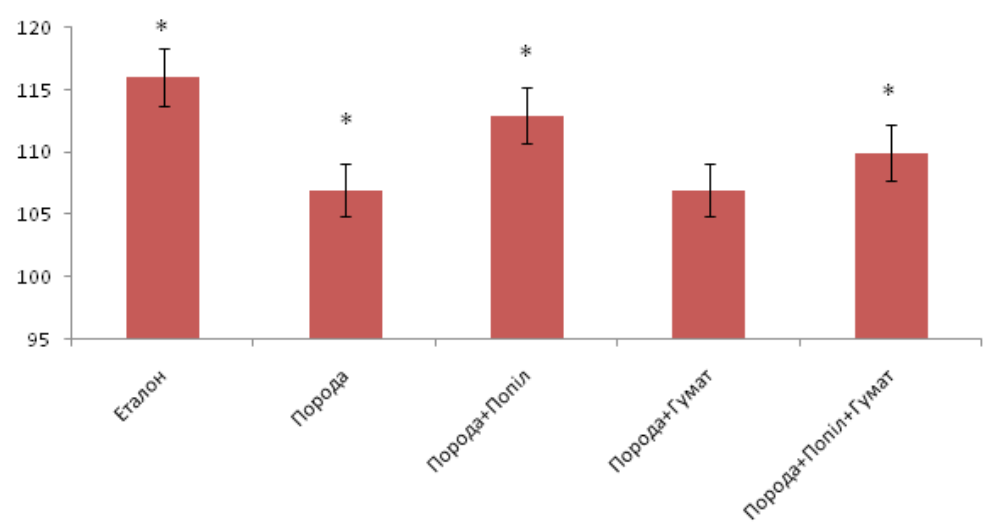

Рис. 3. Вміст органічного карбону в субстраті відвалу за впливу вирощування $S$. drummondii (n=5), \%.

Примітка: * - достовірна різниця значень після вирощування S. drummondii щодо субстрату до нього (100\%) за $\mathrm{p} \leq 0,05$

Натомість, гумат не вплинув на вміст органічного карбону в субстраті. У рослинах, які вирощували на субстраті відвалу, виявлено значне підвищення $\mathrm{C} / \mathrm{N}-$ співвідношення щодо еталону. Додавання попелу знизило його в коренях і листках, а гумату - в коренях, стеблах і листках S. drummondii. 3'ясовано, що внесення обох меліорантів сильніше 
впливає на $\mathrm{C} / \mathrm{N}$-співвідношення в органах рослин, ніж внесення тільки одного 3 них (рис. 4). Зниження співвідношення органічного карбону до валового нітрогену в рослинах можна пояснити зниженням фітотоксичності субстрату відвалу завдяки впливові попелу й гумату.

Таблиця 4

Коефіцієнти кореляції вмісту органічного карбону в органах рослин із його вмістом у субстраті відвалу до і після вирощування $S$. drummondii $(\mathrm{n}=20)$

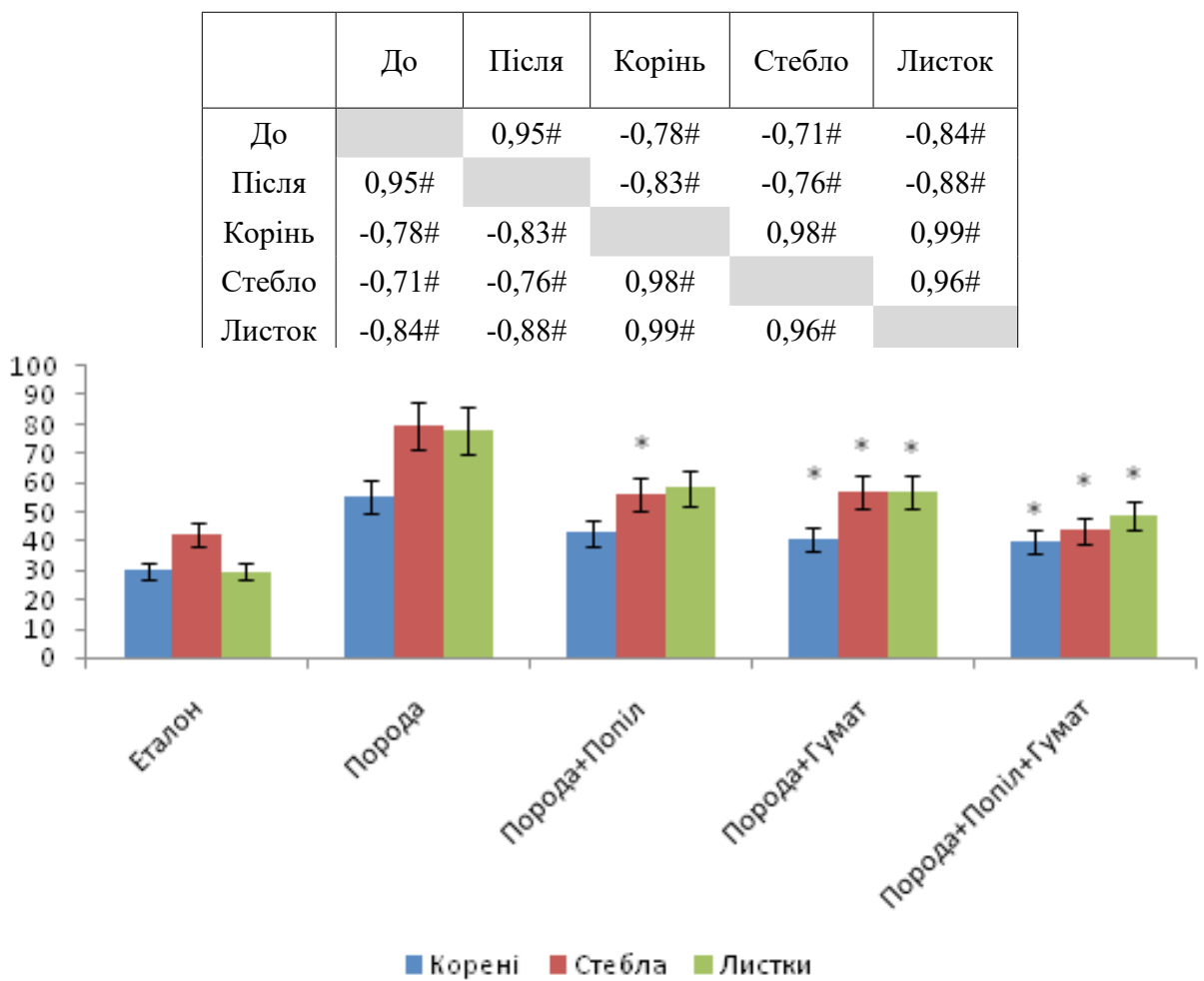

Рис. 4. Вплив попелу й гумату на $\mathrm{C} / \mathrm{N}$-співвідношення в органах $S$. drummondii після вирощування на субстраті породного відвалу $(\mathrm{n}=5)$. Примітка: * - достовірна різниця значень досліду (3 додаванням попелу й гумату) щодо контролю (без додавання попелу й гумату) за $p \leq 0,05$

Отже, сіро-чорна неперегоріла порода відвалу ЦЗФ «Червоноградська» характеризується підвищеним вмістом амонійного нітрогену й органічного карбону. Внесення кам'яновугільного попелу Добротвірської ТЕС і гумату калію «ГКВ-45» спричиняє наближення вмісту обох досліджених макроелементів у субстраті відвалу й органах $S$. drummondii в бік значень умовно оптимального субстрату еталону, що свідчить про ефективність досліджених меліорантів.

\section{СПИСОК ВИКОРИСТАНОЇ ЛІТЕРАТУРИ}

1. Антонова Э. П., Скалабан В. Д., Сучилкина Л. Г. Определение содержания в почвах гумуса // Почвоведение. 1984. № 11. С. 130-133.

2. Аринушкина E. В. Руководство по химическому анализу почв. 2-е изд. М.: МГУ, 1970. $488 \mathrm{c.}$ 
3. Баранов B. Екологічний опис породного відвалу вугільних шахт ЦЗФ ЗАТ «Львівсистеменерго» як суб'єкта озеленення // Вісн. Львів. ун-ту. Сер. біол. 2008. Вип. 46. С. 172-178.

4. Практикум по агрохимии: уч. пособ. 2-е изд., перераб. и доп. / под ред. акад. РАСХН В. Г. Минеева. М.: Изд-во МГУ, 2001. 689 с.

5. Популярні методи аналізу грунтів: метод. рекомендації до курсових і кваліфікаційних робіт / укл. С. М. Польчина. Чернівці: Рута, 2006. 88 с.

6. Шиак Я. В. Фітостресорність породних відвалів кам'яновугільних шахт за впливу попелу ТЕС і гумату калію: дис. ... канд. біол. наук: 03.00.16. Львів, 2020. 168 с.

7. Abramowicz A., Rahmonov O., Fabiańska M. et al. Changes in soil chemical composition caused by self-heating of a coal-waste dump // Land Degrad Dev. 2021. P. 1-10.

8. Dijkstra F., Zhu B., Cheng W. Root effects on soil organic carbon: a double-edged sword // New Phytologist. 2021. Vol. 230. N 1. P. 60-65.

9. Espie P., Ridgway H. Bioactive carbon improves nitrogen fertiliser efficiency and ecological sustainability // Sci. Rep. 2020. Vol. 3227. N 10. P. 1-10.

10. Gojon A. Nitrogen nutrition in plants: rapid progress and new challenges // J. Exp. Bot. 2017. Vol. 68. N 10. P. 2457-2462.

11. Ibrahim S., Ali A. Effect of Potassium Humate Application on Yield and Nutrient Uptake of Maize Grown In a Calcareous Soil // Alex. Sci. Exch. J. 2018. N 39. P. 412-418.

12. Kř́bek B., Sýkorová I., Veselovský F. et al. Trace element geochemistry of self-burning and weathering of a mineralized coal waste dump: The Novátor mine, Czech Republic // Int. J. Coal Geol. 2017. Vol. 173. P. 158-175.

13. Luo W., Li M., Sardans J. et al. Carbon and nitrogen allocation shifts in plants and soils along aridity and fertility gradients in grasslands of China // Ecol. Evol. 2017. Vol. 7. N 17. P. 6927-6934.

14. Lynch M., Mulvaney M., Hodges S. et al. Decomposition, nitrogen and carbon mineralization from food and cover crop residues in the central plateau of Haiti // SpringerPlus. 2016. Vol. 973. N 5. P. 1-9.

15. Mahdi A., Badawy S., Latef A. et al. Integrated Effects of Potassium Humate and Planting Density on Growth, Physiological Traits and Yield of Vicia faba L. Grown in Newly Reclaimed Soil // Agronomy. 2021. Vol. 461. N 11. P. 1-12.

16. Maiti S., Ahirwal J. Chapter 3 - Ecological Restoration of Coal Mine Degraded Lands: Topsoil Management, Pedogenesis, Carbon Sequestration, and Mine Pit Limnology / Editors: Pandey V., Bauddh K. // Phytomanagement of Polluted Sites. Elsevier, 2019. P. 83-11.

17. Mukhopadhyay S., Masto R. Effect of fly ash on carbon mineralization of biochar and organic manures added to mine spoil // SN Appl. Sci. 2019. Vol. 1119. N 1. P. 1-10.

18. Pandey $V$. Phytomanagement of Fly Ash. Elsevier, 2020. 352 p.

19. Roebuck C. Excel HSC chemistry. Glebe: Pascal Press, 2003. 294 p.

20. Tsadilas $C$., $H u$ Z., Bi Y. et al. Utilization of coal fly ash and municipal sewage sludge in agriculture and for reconstruction of soils in disturbed lands: results of case studies from Greece and China // Int. J. Coal. Sci. Technol. 2018. N 5. P. 64-69.

21. Velan M., Prasad M. Chapter 20 - Neyveli Lignite Mine Waste Rehabilitation for Sustainable Development / Bio-Geotechnologies for Mine Site Rehabilitation. Elsevier, 2018. P. 347370.

22. Watt G., Barnett G., Vaska L. Interaction of Alkali Metals and Liquid Ammonia // Ind. Eng. Chem. 1954. Vol. 46. N 5. P. 1022-1024. 
23. Welcha C., Barbourb S., Hendrya M. The geochemistry and hydrology of coal waste rock dumps: A systematic global review // Sci. Total Environ. 2021. Vol. 148798. N 795. P. 1-19.

Стаття надійшла до редакиії 06.10.21

доопрацьована 19.11.21

прийнята до друку 29.11.21

\title{
EFFECT OF COAL FLY ASH AND POTASSIUM HUMATE ON NITROGEN AND CARBON CONTENTS IN COAL INDUSTRY DUMP SUBSTRATE AND ORGANS OF SORGHUM DRUMMONDII (NEES EX STEUD.) MILLSP. \& CHASE
}

\author{
S. Beshley' ${ }^{1}$ V. Baranov' ${ }^{2}$ Y. Shpak ${ }^{2}$ \\ ${ }^{1}$ Institute of Ecology of the Carpathian \\ 4, Kozelnytska St., Lviv 79026, Ukraine \\ ${ }^{2}$ Ivan Franko National University of Lviv \\ 4, Hrushevskyi St., Lviv 79005, Ukraine \\ e-mail:dr.yaroslav.shpak@gmail.com;volodymyr.baranov@lnu.edu.ua
}

Researched ammonium, nitrite and nitrate nitrogen and organic carbon contents in gray-black unburned rock substrate from coal industry waste rock dump of Central Enrichment Factory (CEF) owned by PJSC "Lviv Coal Company" (Lviv Oblast, Ukraine) and total nitrogen and organic carbon contents in organs of Sorghum drummondii (Nees ex Steud.) Millsp. \& Chase under effect of coal fly ash from the Dobrotvir thermal power plant (Lviv Oblast, Ukraine) and potassium humate "ГKB-45" (made by LLC "PARK", Lviv Oblast, Ukraine). Found high content of organic carbon and ammonium nitrogen in waste rock dump substrate with contrast to low content of nitrite and nitrate nitrogen compare to relatively optimal soil mixture of the standard. Detected low carbon and nitrogen contents in organs of $S$. drummondii which grew on the waste rock dump substrate, as well as a significantly increased carbon/nitrogen-ratio (in this research the ratio of organic carbon content to total nitrogen content) compare to plants of the standard. Addition of coal fly ash in waste rock dump substrate decreased ammonium nitrogen and organic carbon contents with contrast to nitrite and nitrate nitrogen increasing, as well as organic carbon and total nitrogen in roots, stalks and leaves of researched plants. Introduction of potassium humate increased nitrite and nitrate nitrogen contents in waste rock dump substrate, organic carbon and total nitrogen contents in organs of $S$. drummondii. Changing of both studied macronutrients contents in plants under the effect of ameliorants caused decreasing carbon/nitrogen-ratio to the direction of the standard values. Growing of S. drummondii grass for 95 days increased organic carbon content in all options of substrates except the rock with potassium humate addition and decreased ammonium, nitrite and nitrate nitrogen contents in all researched options of substrates without exceptions. Noted that combined effect of coal fly ash and potassium humate on carbon and nitrogen contents in waste rock dump substrate and organs of $S$. drummondii is stronger than just one of both above mentioned researched ameliorants. Sorghum

Keywords: carbon/nitrogen-ratio, waste rock dump, coal fly ash, potassium humate, 